\title{
Synthesis and evaluation of anti-oxidant and cytotoxic activities of novel 10 -undecenoic acid methyl ester based lipoconjugates of phenolic acids
}

\author{
Naganna Narra ${ }^{1,2}$, Shiva Shanker Kaki ${ }^{* 1,2, \S}$, Rachapudi Badari Narayana Prasad ${ }^{1,2}$, \\ Sunil Misra ${ }^{2,3}$, Koude Dhevendar ${ }^{2,3}$, Venkateshwarlu Kontham ${ }^{1,2}$ \\ and Padmaja V. Korlipara*1,2,§
}

Open Access

\author{
Full Research Paper \\ Address: \\ ${ }^{1}$ Centre for Lipid Research, CSIR-Indian Institute of Chemical \\ Technology, Uppal Road, Hyderabad 500007, India, ${ }^{2}$ Academy of \\ Scientific and Innovative Research, New Delhi, India and ${ }^{3}$ Biology \\ Division, CSIR-Indian Institute of Chemical Technology, Uppal Road, \\ Hyderabad 500007, India \\ Email: \\ Shiva Shanker Kaki - shivashanker.kaki@iict.res.in; \\ Padmaja V. Korlipara* - kvpadmaja@iict.res.in \\ * Corresponding author \\ $\S \mathrm{Tel} / \mathrm{Fax}+91-40-27193370$ \\ Keywords: \\ anticancer; anti-oxidants; caffeic acid; coumaric acid; ferulic acid; \\ phenolic lipids; sinapic acid; undecenoic acid
}

Beilstein J. Org. Chem. 2017, 13, 26-32. doi:10.3762/bjoc. 13.4

Received: 24 October 2016

Accepted: 19 December 2016

Published: 04 January 2017

This article is part of the Thematic Series "Lipids: fatty acids and derivatives, polyketides and isoprenoids".

Guest Editor: J. S. Dickschat

(c) 2017 Narra et al.; licensee Beilstein-Institut. License and terms: see end of document.

\begin{abstract}
The synthesis of five novel methyl 10-undecenoate-based lipoconjugates of phenolic acids from undecenoic acid was carried out. Undecenoic acid was methylated to methyl 10-undecenoate which was subjected to a thiol-ene reaction with cysteamine hydrochloride. Further amidation of the amine was carried out with different phenolic acids such as caffeic, ferulic, sinapic, coumaric and cinnamic acid. All synthesized compounds were fully characterized and their structures were confirmed by spectral data. The antioxidant activity of the synthesized lipoconjugates of phenolic acids was studied by the 2,2-diphenyl-1-picrylhydrazyl (DPPH) radical scavenging assay and also by the inhibition of linoleic acid oxidation in micellar medium by differential scanning calorimetry (DSC). The prepared compounds were also screened for their cytotoxic activity against five cell lines. It was observed that the lipoconjugates of caffeic acid, sinapic acid, ferulic acid, and coumaric acid displayed anticancer and anti-oxidant properties. The anticancer properties of these derivatives have been assessed by their $\mathrm{IC}_{50}$ inhibitory values in the proliferation of MDA-MB231, SKOV3, MCF7, DU 145 and HepG2 cancer cell lines.
\end{abstract}

\section{Introduction}

Phenolic compounds are a class of natural compounds which are found ubiquitously in the plant kingdom. They are reported to possess a wide range of biological properties like anti- oxidant, antimicrobial, anti-inflammatory, anticarcinogenic and antiviral activities [1]. The phenolic acids are also reported to show in vitro anti-oxidant activity against many reactive oxygen 
species and to protect neuronal cells against various types of oxidative damage [2,3]. To increase the effectiveness of phenolic compounds, their lipophilization has been the choice of derivatization as it provides beneficial effects of both the phenolics and the lipid involved in one chemical entity $[4,5]$. Lipids, especially fatty acids and their derivatives are known for their broad spectrum of activity which expands their application in developing new hybrid biomolecules which help in host defenses against potential pathogenic microbes. Research interest in producing new phenolipids has been increasing due to the potential applications of such products in biomedical fields. Earlier reports on the production of phenolipids were focused on the incorporation of phenolic compounds into triglycerides where a number of phenolic acids were transesterified with different oils or triglycerides [6]. Apart from these structured phenolipids, different fatty acids were esterified with phenolic compounds to produce novel esters which were evaluated for anti-oxidant and antimicrobial activities $[7,8]$. However, there are very few reports where the phenolic acids have been derivatized with other functionalities apart from esters. The reported compounds other than esters were amides where bioconjugates of fatty acids and amino acids were prepared and evaluated for their anti-oxidant activity by a DPPH radical assay [9]. In view of developing new conjugates of phenolic lipids, we have synthesized novel derivatives of phenolic lipids from undecenoic acid where the phenolic acids were linked to the olefinic group of undecenoic acid via a thioamide spacer. Among the various fatty acids reported, 10-undecenoic acid is unique due to its bifunctional nature with an odd-numbered carbon atom chain length derived from castor oil. There have been several reports on the synthesis and evaluation of undecenoic acid-based derivatives due to its wide applicability ranging from biological activity, natural products and polymer applications [10,11]. This type of compounds could be useful as potential novel lipid derivatives because of the presence of lipophilic chain and the phenolic amide conjugate.

\section{Results and Discussion Synthesis}

10 -Undecenoic acid was chosen as the lipid part as the derivatives of undecenoic acid have been reported to be potent bioactive compounds [12,13]. Additionally the terminal double bond of undecenoic acid provides a reactive group for further derivatization for producing potential functional derivatives. The synthetic route followed for the synthesis of the phenolipids is shown in Scheme 1. Initially, undecenoic acid was treated with sulfuric acid in methanol to obtain methyl undecenoate (1) in quantitative yield. Next, ester 1 was treated with 1,1'azobis(cyclohexanecarbonitrile) ( $\mathrm{ABCN})$ and 2-mercaptoethylamine hydrochloride in dioxane/ethanol 70:30 (v:v) to obtain<smiles>C=CCCCCCCCCC(=O)O</smiles><smiles>C=CCCCCCCCCC(=O)OC</smiles>

$\mathrm{ABCN}$

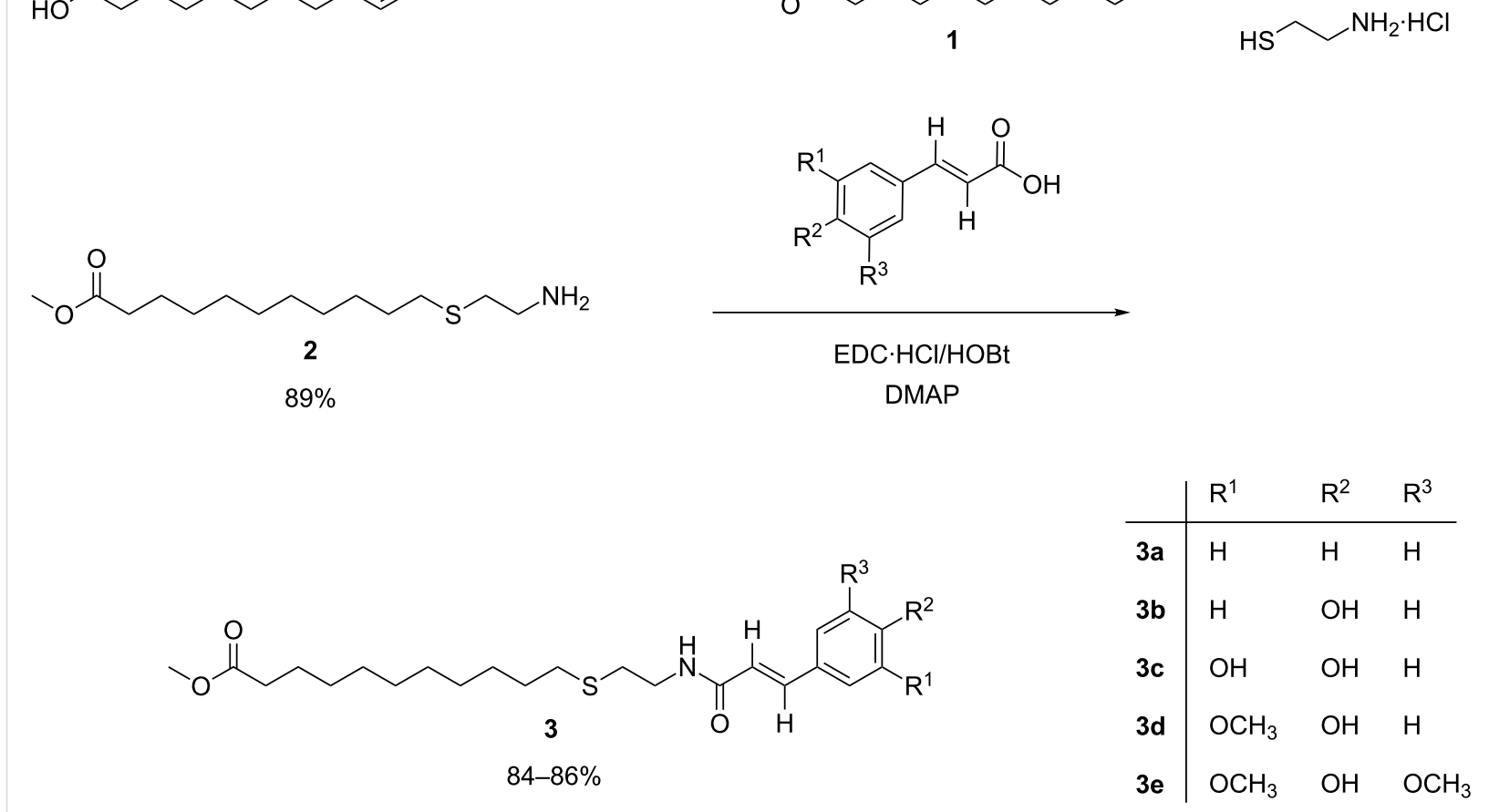


methyl 11-(2-aminoethylthio)undecanoate (2) in $89 \%$ yield. The structures of compounds $\mathbf{1}$ and $\mathbf{2}$ were in agreement with the reported literature data $[14,15]$.

Finally, amine 2 was reacted with different phenolic acids in the presence of $\mathrm{EDC} \cdot \mathrm{HCl}$ and $\mathrm{HOBt}$ to give amides 3a-3e with reproducible yields in the range of $84-86 \%$.

\section{Anti-oxidant activity}

The anti-oxidant activities of the prepared derivatives were studied by the well-established DPPH radical scavenging assay and also by studying the oxidation of linoleic acid using DSC. The DPPH radical is a commercially available stable free radical which is widely used to preliminarily determine the radical scavenging potential of compounds. The results for the ability of the prepared compounds to scavenge the DPPH radical are shown in Table 1 along with reference anti-oxidants $\alpha$-tocopherol ( $\alpha$-TP) and tert-butylhydroquinone (TBHQ). As can be seen, all synthesized derivatives exhibit radical scavenging ability except the cinnamic acid derivative 3a. This could be due to the absence of a phenolic hydroxy group which is responsible for the anti-oxidant activity of most of the natural phytochemicals. Among all compounds, $\mathbf{3 c}$ was found to be the most efficient free radical scavenger which showed a value closest to the standard anti-oxidant, $\alpha$-TP. Compounds $3 \mathbf{d}$ and 3e also showed free radical scavenging activity (FRSA) of $68 \%$ and $67 \%$, respectively, whereas compound $\mathbf{3 b}$ showed only moderate activity with $30 \%$ FRSA.

Table 1: DPPH radical scavenging activity of the synthesized 10-undecenoic acid methyl ester-based lipoconjugates.

Compound $\quad$ FRSA (\%) at $1.0 \mathrm{mM}$ concentration

\begin{tabular}{cc}
\hline 3a & $-^{\mathrm{a}}$ \\
3b & 30.23 \\
3c & 87.05 \\
3d & 67.68 \\
3e & 66.57 \\
a-TP & 90.23 \\
TBHQ & 92.34 \\
\hline
\end{tabular}

${ }^{a}$ no activity.

In another study, the ability of the prepared derivatives in inhibiting the oxidation of linoleic acid was studied by differential scanning calorimetry (DSC). DSC is a sensitive technique and has been used for investigating the thermotropic properties of several compounds including biological macromolecules, drugs and lipid-based materials for their stability and other characteristics [16]. In the present study, pure linoleic acid and linoleic acid containing the synthesized compounds were subjected to DSC analysis. The results of the assay are shown in Table 2 and $\alpha$-TP and TBHQ were included as standard anti-oxidants.

Table 2: DSC study of the synthesized 10-undecenoic acid methy

ester-based lipoconjugates $\mathbf{3 a - e}$

\begin{tabular}{cc} 
Compound $^{\mathrm{a}}$ & OIT $^{\mathrm{b}}\left({ }^{\circ} \mathrm{C}\right)$ \\
\hline $\mathrm{LA}+\mathbf{3 a}$ & 116 \\
$\mathrm{LA}+\mathbf{3 b}$ & 130 \\
$\mathrm{LA}+\mathbf{3 c}$ & 136 \\
$\mathrm{LA}+\mathbf{3 d}$ & 141 \\
$\mathrm{LA}+\mathbf{3 e}$ & 142 \\
$\mathrm{LA}+\mathbf{a}-\mathrm{TP}$ & 130 \\
$\mathrm{LA}+\mathrm{TBHQ}$ & 126 \\
$\mathrm{LA}$ & 116 \\
\hline
\end{tabular}

aLA: linoleic acid, ${ }^{b} \mathrm{OIT}$ : oxidative induction temperature.

Pure linoleic acid showed an oxidative induction temperature (OIT) of $116^{\circ} \mathrm{C}$ which was found to increase when antioxidants were added. It can be observed that the prepared derivatives had a positive influence on the oxidation of linoleic acid except for derivative 3a which did not show any anti-oxidant activity (see Supporting Information File 1, Figure S20 for DSC curves). All other derivatives were found to exhibit very good protective activity against oxidation of linoleic acid and the OITs were found to be similar or in case of compounds $\mathbf{3 c}, \mathbf{3 d}$ and $3 \mathbf{e}$ even higher compared to the reference anti-oxidants TBHQ and $\alpha$-TP. The OIT for TBHQ and $\alpha$-TP were observed to be 126 and $130{ }^{\circ} \mathrm{C}$, respectively, whereas compound $\mathbf{3 b}$ showed an OIT of $130^{\circ} \mathrm{C}$. As the anti-oxidant activity has been reported [17] to depend on several factors such as the medium of an assay, number and position of phenolic hydroxy groups, etc. the differences in the anti-oxidant potentials of the prepared phenolipids could be due to different media used for the assays; the DPPH assay is conducted in a polar medium but the linoleic acid oxidation study is conducted in a non-polar environment.

\section{Cytotoxic activity}

As there were studies reported on the cytotoxicity of phenolic lipids, we have further screened the prepared compounds for their anticancer activity [18]. The anticancer activity of compounds 3a-e was tested against five cell lines along with doxorubicin as positive control and all of them showed moderate to good anticancer effects. The results are collected in Table 3 . The compounds whose $\mathrm{IC}_{50}$ values are observed to be lower and closer to the reference drug are considered as having good anticancer potential. 
Table 3: Anticancer activity of 10-undecenoic acid methyl ester-based lipoconjugates. ${ }^{\text {a }}$

\begin{tabular}{|c|c|c|c|c|c|c|}
\hline \multirow[t]{2}{*}{ Entry } & \multirow[t]{2}{*}{ Compound } & \multicolumn{5}{|c|}{$\mathrm{IC}_{50}$ values $(\mu \mathrm{M})$} \\
\hline & & MDA-MB-231 & SKOV3 & MCF7 & DU145 & HepG2 \\
\hline 1 & $3 a$ & $21.2 \pm 0.31$ & $99.2 \pm 0.79$ & $17.2 \pm 0.23$ & $25.4 \pm 0.31$ & $38.2 \pm 0.42$ \\
\hline 2 & $3 b$ & $14.5 \pm 0.26$ & $31.5 \pm 0.41$ & $39.2 \pm 0.45$ & $81.6 \pm 0.77$ & $58.3 \pm 0.61$ \\
\hline 3 & $3 c$ & $12.0 \pm 0.28$ & $38.9 \pm 0.37$ & $10.55 \pm 0.27$ & $13.0 \pm 0.26$ & $67.4 \pm 0.59$ \\
\hline 4 & $3 d$ & $29.0 \pm 0.36$ & $32.2 \pm 0.32$ & $28.8 \pm 0.36$ & $56.7 \pm 0.62$ & $93.9 \pm 0.85$ \\
\hline \multirow[t]{2}{*}{5} & $3 e$ & $12.5 \pm 0.25$ & $38.3 \pm 0.40$ & $13.9 \pm 0.22$ & $28.8 \pm 0.39$ & $141.4 \pm 0.98$ \\
\hline & doxorubicin & $0.8 \pm 0.14$ & $0.7 \pm 0.16$ & $0.8 \pm 0.12$ & $0.8 \pm 0.15$ & $0.7 \pm 0.14$ \\
\hline
\end{tabular}

a Cell lines: MDA-MB-231, breast cancer (ATCC ${ }^{\circledR}$ HTB-26 ${ }^{\mathrm{TM}}$ ); SKOV3, ovarian cancer (ATCC ${ }^{\circledR}$ HTB-77 ${ }^{\text {TM }}$ ); MCF7, breast cancer $\left(\right.$ ATCC ${ }^{\circledR}$ HTB-22 $^{\text {TM }}$ ); DU 145, prostate cancer (ATCC ${ }^{\circledR}$ HTB-81 ${ }^{\mathrm{TM}}$ ); HepG2, liver hepatocellular carcinoma $\left(\right.$ ATCC $^{\circledR} \mathrm{HB}-8065^{\mathrm{TM}}$ ).

Specifically compounds $\mathbf{3 c}, \mathbf{3 b}$ and $\mathbf{3 e}$ were found to show promising anticancer activity according to their $\mathrm{IC}_{50}$ values, whereas 3d and 3a exhibited only moderate activity. Among all tested derivatives, compound $\mathbf{3 c}$ was found to exhibit best anticancer activity against MCF7, DU145 and MDA-MB-231 cell lines with $\mathrm{IC}_{50}$ values of $10.55,13.0$ and $12.0 \mu \mathrm{M}$, respectively. It was found that the anticancer activity against some cell lines was much better compared to our previous reports on phenolic lipids [19]. However, all prepared derivatives were observed to exhibit lower anticancer activity when compared to the reference drug doxorubicin which showed $\mathrm{IC}_{50}$ values in the range of 0.7 to $0.8 \mu \mathrm{M}$ against the tested cell lines.

\section{Conclusion}

In conclusion, the synthesis of five novel methyl 10-undecenoate-based lipoconjugates of phenolic acids is reported. The synthetic route was simple with product yields in the range of $84-86 \%$ over three steps. The lipid part, methyl 10 -undecenoate was subjected to a thiol-ene reaction with cysteamine hydrochloride and the resulting intermediate was conjugated with the phenolic acid via amidation. The evaluation of the five novel phenolic lipids as anti-oxidants was studied using the DPPH radical scavenging assay and DSC studies where some compounds showed excellent anti-oxidant activity. Finally the compounds were further screened for anticancer activity where a few derivatives showed interesting activity.

\section{Experimental Materials}

10-Undecenoic acid, 1,1'-azobis(cyclohexanecarbonitrile) $(\mathrm{ABCN})$, hydroxybenzotriazole (HOBt) and 1-ethyl-3-(3'dimethylaminopropyl)carbodiimide hydrochloride (EDC $\cdot \mathrm{HCl})$, cysteamine hydrochloride, cinnamic acid, sinapic acid, ferulic acid, $p$-coumaric acid, caffeic acid, $\alpha$-tocopherol $(\alpha-\mathrm{TP})$, tertbutylhydroquinone (TBHQ), linoleic acid (LA) and 2,2diphenyl-1-picrylhydrazyl (DPPH) radical were purchased from
Sigma-Aldrich (St.Louis, USA), and pre-coated TLC plates (silica gel 60 F254) were purchased from Merck (Darmstadt, Germany). All solvents were purchased from Sd Fine Chemicals (Mumbai, India) and were of the highest grade of purity available.

\section{Instruments}

${ }^{1} \mathrm{H}$ and ${ }^{13} \mathrm{C}$ NMR spectra were recorded on a Bruker Avance operating at 700/500 MHz and 175/125 MHz. The NMR spectra were referenced to $\delta 7.26 \mathrm{ppm}$ and $\delta 77.0 \mathrm{ppm}$ in $\mathrm{CDCl}_{3}$ solvent for ${ }^{1} \mathrm{H}$ and ${ }^{13} \mathrm{C}$, respectively. Coupling constants $(J)$ patterns in the ${ }^{1} \mathrm{H}$ NMR spectra are given as follows: $\mathrm{s}=$ singlet, $\mathrm{d}=$ doublet, $\mathrm{t}=$ triplet, $\mathrm{q}=$ quartet, $\mathrm{m}=$ multiplet protons. Mass spectra were recorded using electron spray ionization (ESI) on a Waters e2695 Separators module (Waters, Milford, MA, USA) mass spectrometer. FTIR spectra were recorded in chloroform on a Perkin-Elmer Fourier Transform (FTIR) spectrum BX instrument (Model: Spectrum BX; Connecticut, USA). HRMS spectra were obtained from an Exactive Orbitrap mass spectrometer (Thermo Scientific, Waltham, MA, USA). Melting points of lipoconjugates of phenolic molecules were determined with a capillary tube melting point apparatus. Gas chromatography (GC) was performed on an Agilent 6890N gas chromatograph (Delaware, USA) equipped with a flame ionization detector using a HP-1 capillary column $(30 \mathrm{~m} \times 0.25 \mathrm{~mm} \times 0.25 \mu \mathrm{m})$. The injector and detector temperatures were set at 280 and $300{ }^{\circ} \mathrm{C}$, respectively. The oven temperature was programmed at $150{ }^{\circ} \mathrm{C}$ for $2 \mathrm{~min}$ and then increased to $300{ }^{\circ} \mathrm{C}$ at $10{ }^{\circ} \mathrm{C} / \mathrm{min}$ and final temperature hold for $20 \mathrm{~min}$. The carrier gas used was nitrogen at a flow rate of $1.0 \mathrm{~mL} / \mathrm{min}$.

\section{Methods}

Synthesis of methyl undec-10-enoate (1): 10-Undecenoic acid (10 g, $54.34 \mathrm{mmol})$, was added to methanol $(17.6 \mathrm{~mL})$ and sulfuric acid $(0.1 \mathrm{~mL}, 2 \mathrm{wt} \% 10$-undecenoic acid $)$ and stirred at 
refluxing temperature of methanol for $6 \mathrm{~h}$. After completion of the reaction as shown by TLC (hexane/ethyl acetate 80:20, v/v), excess methanol was removed under reduced pressure and the product was diluted with ethyl acetate $(30 \mathrm{~mL})$, washed with $5 \%$ aqueous $\mathrm{NaHCO}_{3}$ solution $(3 \times 30 \mathrm{~mL})$, and dried over anhydrous $\mathrm{Na}_{2} \mathrm{SO}_{4}$. The organic solvent was removed under reduced pressure to afford crude methyl ester of 10-undecenoic acid. The product was purified by column chromatography with basic alumina and hexane as the eluent to get $99 \%$ pure methyl undec-10-enoate (1) as indicated by GC. The product was analyzed by ${ }^{1} \mathrm{H}$ NMR, ${ }^{13} \mathrm{C}$ NMR, ESIMS, and FTIR and the structure was confirmed by comparing the data with those reported in the literature [14].

Synthesis of methyl 11-(2-aminoethylthio) undecanoate (2): For the synthesis of compound $\mathbf{2}$, a reported protocol was followed with slight modifications [20]. Briefly, methyl undecenoate (1, $6 \mathrm{~g}, 30.3 \mathrm{mmol})$ and $\mathrm{ABCN}(0.18 \mathrm{~g}, 3 \mathrm{wt} \%$ of $\mathbf{1})$ were dissolved in $40 \mathrm{~mL}$ chloroform. Then, 2-mercaptoethylamine hydrochloride $(6.8 \mathrm{~g}, 60 \mathrm{mmol})$ and $40 \mathrm{~mL}$ of $1,4-$ dioxane/ethanol $(70: 30 ; \mathrm{v} / \mathrm{v})$ were added and the mixture was stirred at $85^{\circ} \mathrm{C}$ for $48 \mathrm{~h}$. The progress of the reaction was monitored by TLC (hexane/ethyl acetate $80: 20, \mathrm{v} / \mathrm{v}$ ). After maximum conversion, the reaction mixture was extracted with dichloromethane $(2 \times 40 \mathrm{~mL})$ and the combined organic phases were washed with saturated $\mathrm{K}_{2} \mathrm{CO}_{3}$, brine and finally with water and dried over anhydrous $\mathrm{Na}_{2} \mathrm{SO}_{4}$. This crude product mixture was concentrated and purified by column chromatography with hexane/ethyl acetate $(92: 8, \mathrm{v} / \mathrm{v})$ to obtain pure methyl 11-(2aminoethylthio)undecanoate (2) in $89 \%$ yield (7.41 g). The purified product was characterized by ${ }^{1} \mathrm{H}$ and ${ }^{13} \mathrm{C}$ NMR, IR and ESIMS spectral studies and the structure was confirmed by comparing the data with those reported in the literature [15].

Synthesis of methyl 11-((2-(cinnamamido)ethyl)sulfanyl)undecanoate (3a): The amidation reaction was performed following a reported protocol with slight modifications [21]. Briefly, compound $2(0.58 \mathrm{~g}, 2.1 \mathrm{mmol})$ and cinnamic acid $(0.4 \mathrm{~g}, 3.1 \mathrm{mmol})$ were dissolved in dichloromethane $(30 \mathrm{~mL})$ and the mixture was stirred at $0-5{ }^{\circ} \mathrm{C}$ under a nitrogen atmosphere. $\mathrm{EDC} \cdot \mathrm{HCl}(0.4 \mathrm{~g}, 2.52 \mathrm{mmol})$ and $\mathrm{HOBt}(0.3 \mathrm{~g}$, $3.1 \mathrm{mmol}$ ) were added and the contents were stirred at $0-5{ }^{\circ} \mathrm{C}$ for $10 \mathrm{~min}$. After the addition, the mixture was stirred for $12 \mathrm{~h}$ at $\mathrm{rt}$ under a nitrogen atmosphere and the progress of reaction was monitored by TLC using the solvent system chloroform/ methanol $(80: 20, \mathrm{v} / \mathrm{v})$. After maximum conversion, the reaction mixture was extracted with dichloromethane, washed with water and dried over anhydrous $\mathrm{Na}_{2} \mathrm{SO}_{4}$ and concentrated to obtain the crude product. The crude product was purified by column chromatography (chloroform/methanol 90:10, v/v) to obtain the thioamide of cinnamic acid in $86 \%$ yield $(0.73 \mathrm{~g})$.
The product was characterized by ${ }^{1} \mathrm{H}$ and ${ }^{13} \mathrm{C}$ NMR, IR, ESIMS and HRMS spectral studies. Mp 55-56 ${ }^{\circ} \mathrm{C} ;{ }^{1} \mathrm{H}$ NMR (500 MHz, $\left.\mathrm{CDCl}_{3}\right) \delta 7.64(\mathrm{~d}, J=15.6 \mathrm{~Hz}, 1 \mathrm{H}), 7.54-7.46(\mathrm{~m}, 5 \mathrm{H}), 6.24(\mathrm{~d}$, $J=15.6 \mathrm{~Hz}, 1 \mathrm{H}), 3.66(\mathrm{~s}, 3 \mathrm{H}), 3.56(\mathrm{q}, 2 \mathrm{H}), 2.73(\mathrm{t}, 2 \mathrm{H}), 2.58$ $(\mathrm{t}, 2 \mathrm{H}), 2.30(\mathrm{t}, 2 \mathrm{H}), 1.24-1.62\left(\mathrm{~m}, 12 \mathrm{H}, \mathrm{CH}_{2}\right) ;{ }^{13} \mathrm{C} \mathrm{NMR}$ $\left(75 \mathrm{MHz}, \mathrm{CDCl}_{3}\right) \delta 174.37\left(-\mathrm{C}(\mathrm{O})-\mathrm{OCH}_{3}\right), 165.50$ $(-\mathrm{NH}-\mathrm{C}(\mathrm{O})-), 141.25(-\mathrm{NH}-\mathrm{C}(\mathrm{O})-\mathrm{CH}=\mathrm{CH}-), 134.81-127.83$, 120.52 (-NH-C(O)- $\mathrm{CH}=\mathrm{CH}-), 51.47\left(-\mathrm{C}(\mathrm{O})-\mathrm{OCH}_{3}-\right), 38.49$ (- $\left.\mathrm{CH}_{2}-\mathrm{NH}-\right), 29.44\left(-\mathrm{S}-\mathrm{CH}_{2}-\right), 29.36\left(-\mathrm{CH}_{2}-\mathrm{S}-\right), 29.22\left(-\mathrm{CH}_{2}-\right.$ $\left.\mathrm{CH}_{2}-\mathrm{S}-\right)$, 29.19-24.96 (- $\left.\mathrm{CH}_{2}-\mathrm{CH}_{2}-\right)$; IR $\left(\mathrm{cm}^{-1}, \mathrm{KBr}\right): 2853$, 2853, 1720, 1654, 1599, 1527, 1441, 1365; ESIMS (m/z): 406 $[\mathrm{M}+\mathrm{H}]^{+}, 428[\mathrm{M}+\mathrm{Na}]^{+}$; HRMS $(\mathrm{m} / \mathrm{z}):[\mathrm{M}+\mathrm{H}]^{+}$calcd for $\mathrm{C}_{23} \mathrm{H}_{36} \mathrm{O}_{3} \mathrm{NS}$, 406.24104; found, 406.24077.

Synthesis of methyl 11-((2-((E)-3-(4-hydroxyphenyl)acrylamido)ethyl)sulfanyl)undecanoate (3b): Similarly, methyl 11-((2-((E)-3-(4-hydroxyphenyl)acrylamido)ethyl)sulfanyl)undecanoate (3b) was prepared from $2(0.6 \mathrm{~g}, 2.1 \mathrm{mmol})$ and coumaric acid $(0.5 \mathrm{~g}, 3.2 \mathrm{mmol})$ in $85 \%$ yield $(0.78 \mathrm{~g})$ and the product was characterized by ${ }^{1} \mathrm{H}$ and ${ }^{13} \mathrm{C} \mathrm{NMR}$, IR, ESIMS and HRMS spectral studies. Mp 64-65 ${ }^{\circ} \mathrm{C} ;{ }^{1} \mathrm{H}$ NMR $(500 \mathrm{MHz}$, $\left.\mathrm{CDCl}_{3}\right) \delta 7.57(\mathrm{~d}, J=15.6 \mathrm{~Hz}, 1 \mathrm{H}), 7.39(\mathrm{~d}, J=8.6 \mathrm{~Hz}, 1 \mathrm{H})$, $6.85(\mathrm{~d}, J=8.6 \mathrm{~Hz}, 1 \mathrm{H}), 6.26(\mathrm{~d}, J=15.6 \mathrm{~Hz}, 1 \mathrm{H}), 3.67(\mathrm{~s}, 3 \mathrm{H})$, $3.58(\mathrm{q}, 2 \mathrm{H}), 2.73(\mathrm{t}, 2 \mathrm{H}), 2.58(\mathrm{t}, 2 \mathrm{H}), 2.30(\mathrm{t}, 2 \mathrm{H}), 1.24-1.62$ $\left(\mathrm{m}, 12 \mathrm{H}, \mathrm{CH}_{2}\right) ;{ }^{13} \mathrm{C} \mathrm{NMR}\left(75 \mathrm{MHz}, \mathrm{CDCl}_{3}\right) \delta 174.71(-\mathrm{C}(\mathrm{O})-$ $\left.\mathrm{OCH}_{3}\right), 166.84$ (-NH-C(O)-), 158.33, 141.51 (-NH-C(O)$\mathrm{CH}=\mathrm{CH}-), 129.64,128.99,117.32(-\mathrm{NH}-\mathrm{C}(\mathrm{O})-\mathrm{CH}=\mathrm{CH}-)$, $115.98,51.58$ (-C(O)-OCH$\left.{ }_{3}^{-}\right), 38.63$ (-CH $\left.\mathrm{CH}_{2}-\mathrm{NH}-\right), 34.16$ (-S$\left.\mathrm{CH}_{2}-\right), 31.89$ (- $\left.\mathrm{CH}_{2}-\mathrm{S}-\right), 31.84$ (- $\left.\mathrm{CH}_{2}-\mathrm{CH}_{2}-\mathrm{S}-\right), 29.69-24.96$ $\left(-\mathrm{CH}_{2}-\mathrm{CH}_{2}-\right)$; IR ( $\left.\mathrm{cm}^{-1}, \mathrm{KBr}\right): 3409,2923,2853,1729,1652$, 1595, 1519, 1452, 1373; ESIMS $(\mathrm{m} / z): 422[\mathrm{M}+\mathrm{H}]^{+}, 444$ $[\mathrm{M}+\mathrm{Na}]^{+}$; HRMS $(\mathrm{m} / \mathrm{z}):[\mathrm{M}+\mathrm{H}]^{+}$calcd for $\mathrm{C}_{26} \mathrm{H}_{36} \mathrm{O}_{4} \mathrm{NS}$, 422.23596; found, 422.23491 .

Synthesis of methyl 11-((2-((E)-3-(3,4-dihydroxyphenyl)acrylamido)ethyl)sulfanyl)undecanoate (3c): Similarly, methyl 11-((2-((E)-3-(3,4-dihydroxyphenyl)acrylamido)ethyl)sulfanyl)undecanoate was prepared from 2 (0.6 g, $2.1 \mathrm{mmol})$ and caffeic acid $(0.5 \mathrm{~g}, 3.2 \mathrm{mmol})$ in $85 \%$ yield $(0.81 \mathrm{~g})$ and the product was characterized by ${ }^{1} \mathrm{H}$ and ${ }^{13} \mathrm{C}$ NMR, IR, ESIMS and HRMS spectral studies. ${ }^{1} \mathrm{H}$ NMR $\left(500 \mathrm{MHz}, \mathrm{CDCl}_{3}\right) \delta 7.55(\mathrm{~d}, J=15.6 \mathrm{~Hz}, 1 \mathrm{H}), 7.12(\mathrm{~d}, J=8.6$ $\mathrm{Hz}, 1 \mathrm{H}), 6.95(\mathrm{~s}, 1 \mathrm{H}) 6.87(\mathrm{~d}, J=8.6 \mathrm{~Hz}, 1 \mathrm{H}), 6.24(\mathrm{~d}, J=15.6$ $\mathrm{Hz}, 1 \mathrm{H}), 3.68$ (s, 3H), $3.56(\mathrm{q}, 2 \mathrm{H}), 2.73(\mathrm{t}, 2 \mathrm{H}), 2.58(\mathrm{t}, 2 \mathrm{H})$, $2.30(\mathrm{t}, 2 \mathrm{H}), 1.24-1.62\left(\mathrm{~m}, 12 \mathrm{H}, \mathrm{CH}_{2}\right) ;{ }^{13} \mathrm{C} \mathrm{NMR}(75 \mathrm{MHz}$, $\left.\mathrm{CDCl}_{3}\right) \delta 174.74\left(-\mathrm{C}(\mathrm{O})-\mathrm{OCH}_{3}\right), 167.38$ (-NH-C(O)-), 146.87, 144.53, 142.53 (-NH-C(O)-CH=CH-), 127.07, 121.33, 117.12 (-NH-C(O)- $\mathrm{CH}=\mathrm{CH}-), 115.46,114.71,51.60$ (-C(O)- $\left.\mathrm{OCH}_{3}^{-}\right)$, 39.05 (- $\left.\mathrm{CH}_{2}-\mathrm{NH}-\right), 38.88$ (-S- $\left.\mathrm{CH}_{2}-\right), 38.76\left(-\mathrm{CH}_{2}-\mathrm{S}-\right), 34.16$ (- $\left.\mathrm{CH}_{2}-\mathrm{CH}_{2}-\mathrm{S}-\right)$, 29.59-24.96 $\left(-\mathrm{CH}_{2}-\mathrm{CH}_{2}-\right)$; IR $\left(\mathrm{cm}^{-1}, \mathrm{KBr}\right)$ : 3359, 2953, 2854, 1721, 1654, 1599, 1527, 1441, 1365; ESIMS 
$(m / z): 438[\mathrm{M}+\mathrm{H}]^{+}, 460[\mathrm{M}+\mathrm{Na}]^{+} ; \operatorname{HRMS}(\mathrm{m} / \mathrm{z}):$ $[\mathrm{M}+\mathrm{H}]^{+}$calcd for $\mathrm{C}_{23} \mathrm{H}_{36} \mathrm{O}_{5} \mathrm{NS}, 438.23087$; found, 438.23023 .

Synthesis of methyl 11-((2-((E)-3-(4-hydroxy-3-methoxyphenyl)acrylamido)ethyl)sulfanyl)undecanoate (3d): Similarly, methyl 11-((2-((E)-3-(4-hydroxy-3-methoxyphenyl)acrylamido)ethyl)sulfanyl)undecanoate was prepared from $2(0.6 \mathrm{~g}$, $2.1 \mathrm{mmol})$ and ferulic acid (0.6 g, $3.2 \mathrm{mmol})$ in $84 \%$ yield $(0.82 \mathrm{~g})$ and the product was characterized by ${ }^{1} \mathrm{H}$ and ${ }^{13} \mathrm{C}$ NMR, IR, ESIMS and HRMS spectral studies. ${ }^{1} \mathrm{H}$ NMR $\left(500 \mathrm{MHz}, \mathrm{CDCl}_{3}\right) \delta 7.55(\mathrm{~d}, J=15.5 \mathrm{~Hz}, 1 \mathrm{H}), 7.06(\mathrm{dd}, J=$ $8.2,1.5 \mathrm{~Hz}, 1 \mathrm{H}), 7.00(\mathrm{~d}, J=1.6 \mathrm{~Hz}, 1 \mathrm{H}), 6.91(\mathrm{~d}, J=8.2 \mathrm{~Hz}$, $1 \mathrm{H}), 6.27(\mathrm{~d}, J=15.5 \mathrm{~Hz}, 1 \mathrm{H}), 3.92(\mathrm{~s}, 3 \mathrm{H}), 3.67(\mathrm{~s}, 3 \mathrm{H}), 3.58$ (q, 2H), $2.73(\mathrm{t}, 2 \mathrm{H}), 2.58(\mathrm{t}, 2 \mathrm{H}), 2.30(\mathrm{t}, 2 \mathrm{H}), 1.24-1.62(\mathrm{~m}$, $\left.12 \mathrm{H}, \mathrm{CH}_{2}\right) ;{ }^{13} \mathrm{C}$ NMR $\left(75 \mathrm{MHz}, \mathrm{CDCl}_{3}\right) \delta 174.36(-\mathrm{C}(\mathrm{O})-$ $\left.\mathrm{OCH}_{3}\right), 166.21$ (-NH-C(O)-), 147.48, 146.76, 141.26 (-NH$\mathrm{C}(\mathrm{O})-\mathrm{CH}=\mathrm{CH}-), 127.33,122.22,118.06(-\mathrm{NH}-\mathrm{C}(\mathrm{O})-\mathrm{CH}=\mathrm{CH}-)$, 114.76, 109.64, $55.95\left(-\mathrm{OCH}_{3}-\right), 51.45\left(-\mathrm{C}(\mathrm{O})-\mathrm{OCH}_{3}-\right), 38.42$ $\left(-\mathrm{CH}_{2}-\mathrm{NH}-\right), 34.11\left(-\mathrm{S}-\mathrm{CH}_{2}-\right), 31.97\left(-\mathrm{CH}_{2}-\mathrm{S}\right), 31.74\left(-\mathrm{CH}_{2}-\right.$ $\mathrm{CH}_{2}$-S-), 29.47-24.95 (- $\left.\mathrm{CH}_{2}-\mathrm{CH}_{2}-\right)$; IR ( $\left.\mathrm{cm}^{-1}, \mathrm{KBr}\right): 3375$, 2926, 2853, 1730, 1656, 1596, 1516, 1433, 1273; ESIMS ( $\mathrm{m} / \mathrm{z})$ $452[\mathrm{M}+\mathrm{H}]^{+}, 474[\mathrm{M}+\mathrm{Na}]^{+}$; HRMS $(\mathrm{m} / \mathrm{z}):[\mathrm{M}+\mathrm{H}]^{+}$calcd for $\mathrm{C}_{24} \mathrm{H}_{38} \mathrm{O}_{5} \mathrm{NS}$, 452.24652; found, 452.24475 .

Synthesis of methyl-11-((2-((E)-3-(4-hydroxy-3,5-dimethoxyphenyl)acrylamido)ethyl)sulfanyl)undecanoate (3e): Similarly, methyl 11-((2-((E)-3-(4-hydroxy-3,5-dimethoxyphenyl)acrylamido)ethyl)sulfanyl)undecanoate was prepared from 2 $(0.6 \mathrm{~g}, 2.1 \mathrm{mmol})$ and sinapic acid $(0.7 \mathrm{~g}, 3.2 \mathrm{mmol})$ in $85 \%$ yield $(0.89 \mathrm{~g})$ and the product was characterized by ${ }^{1} \mathrm{H}$ and ${ }^{13} \mathrm{C}$ NMR, IR, ESIMS and HRMS spectral studies. Mp 69-70 ${ }^{\circ} \mathrm{C} ;{ }^{1} \mathrm{H}$ NMR $\left(500 \mathrm{MHz}, \mathrm{CDCl}_{3}\right) \delta 7.53(\mathrm{~d}, J=15.5$ $\mathrm{Hz}, 1 \mathrm{H}), 6.76(\mathrm{~s}, J=8.2,1.5 \mathrm{~Hz}, 2 \mathrm{H}), 6.28(\mathrm{~d}, J=15.5 \mathrm{~Hz}, 1 \mathrm{H})$, $3.93(\mathrm{~s}, 6 \mathrm{H}), 3.67(\mathrm{~s}, 3 \mathrm{H}), 3.58(\mathrm{q}, 2 \mathrm{H}), 2.73(\mathrm{t}, 2 \mathrm{H}), 2.58(\mathrm{t}$, $2 \mathrm{H}), 2.30(\mathrm{t}, 2 \mathrm{H}), 1.24-1.62\left(\mathrm{~m}, 12 \mathrm{H}, \mathrm{CH}_{2}\right) ;{ }^{13} \mathrm{C} \mathrm{NMR}$ $\left(75 \mathrm{MHz}, \mathrm{CDCl}_{3}\right) \delta 174.37\left(-\mathrm{C}(\mathrm{O})-\mathrm{OCH}_{3}\right), 166.07$ (-NH-C(O)-), 147.22, 141.43 (-NH-C(O)-CH=CH-),136.64, $126.29,118.44$ (-NH-C(O)- $\mathrm{CH}=\mathrm{CH}-), 104.82,56.34\left(-\mathrm{OCH}_{3}{ }^{-}\right)$, 51.48 (-C(O)-OCH $\left.3_{3}^{-}\right), 38.39$ (- $\left.\mathrm{CH}_{2}-\mathrm{NH}-\right), 34.11$ (-S- $\left.\mathrm{CH}_{2}-\right)$, 31.96 (- $\left.\mathrm{CH}_{2}-\mathrm{S}-\right), 31.69\left(-\mathrm{CH}_{2}-\mathrm{CH}_{2}-\mathrm{S}-\right), 29.65-24.95\left(-\mathrm{CH}_{2}-\right.$ $\mathrm{CH}_{2^{-}}$); IR ( $\left.\mathrm{cm}^{-1}, \mathrm{KBr}\right): 3371,2926,2852,1730,1658,1612$, 1514, 1455 1285; $\operatorname{ESIMS~}(\mathrm{m} / \mathrm{z}): 482[\mathrm{M}+\mathrm{H}]^{+}, 504[\mathrm{M}+\mathrm{Na}]^{+}$; HRMS $(m / z):[\mathrm{M}+\mathrm{H}]^{+}$calcd for $\mathrm{C}_{25} \mathrm{H}_{40} \mathrm{O}_{6} \mathrm{NS}, 482.25709$; found, 482.25532 .

\section{Anti-oxidant activity $\mathrm{DPPH}$ radical scavenging assay}

The anti-oxidant activity was determined by the radical scavenging ability using the stable DPPH radical method as reported [22]. Briefly, $200 \mu \mathrm{L}$ of a methanolic solution of the syn- thesized phenolic lipoconjugates ( $1 \mathrm{mM}$ concentrations) were added to $2 \mathrm{~mL}$ of a methanolic solution of the DPPH radical ( $1 \mathrm{mM}$ concentration) and the total volume was made up to $3 \mathrm{~mL}$ with methanol. After $40 \mathrm{~min}$ of standing, the absorbance of the mixture was measured at $517 \mathrm{~nm}$ against methanol as blank sample. TBHQ and $\alpha$-TP (1 mM concentration) were used as a positive control. The radical-scavenging activities (\%) of the tested samples were evaluated by comparison with the control (2 mL DPPH radical solution and $1 \mathrm{~mL}$ methanol). Each sample was measured in triplicate and averaged. The freeradical scavenging activity (FRSA) was calculated using the following formula: FRSA $=[(A \mathrm{c}-A \mathrm{~s}) / A \mathrm{c}] \times 100$ where $A \mathrm{c}$ is the absorbance of the control and $A \mathrm{~s}$ is the absorbance of the tested sample after $40 \mathrm{~min}$.

\section{DSC measurements}

The anti-oxidant activity was also evaluated by differential scanning calorimetry using pure linoleic acid as a lipid model system [23,24]. All studied anti-oxidants were dissolved in methanol to prepare $1 \mathrm{mM}$ solutions. Samples of linoleic acid $(2.5-3.0 \mathrm{mg})$ were placed in standard aluminum pans and spiked with $10 \mu \mathrm{L}$ of the anti-oxidant solution. A blank run of linoleic acid, spiked with $10 \mu \mathrm{L}$ of methanol was also carried out simultaneously to find the oxidative induction temperature (OIT) of linoleic acid. OIT is determined from the first exothermal peak of the plot of heat flow $(\mathrm{mW} / \mathrm{g})$ vs temperature. All measurements for each compound were run in triplicate and the results were averaged.

\section{Cytotoxicity test (MTT assay)}

The cytotoxicity assay (MTT) was evaluated for all test compounds as described in our earlier work [25]. Five different cancer cell lines viz., MDA-MB-231, breast cancer (ATCC ${ }^{\circledR}$ HTB-26 ${ }^{\mathrm{TM}}$ ); SKOV3, ovarian cancer (ATCC ${ }^{\circledR}$ HTB-77 ${ }^{\mathrm{TM}}$ ); MCF7, breast cancer $\left(\mathrm{ATCC}^{\circledR} \mathrm{HTB}-22^{\mathrm{TM}}\right.$ ); DU 145, prostate cancer (ATCC ${ }^{\circledR}$ HTB-81 ${ }^{\mathrm{TM}}$ ); HepG2, liver hepatocellular carcinoma (ATCC ${ }^{\circledR}$ HB-8065 ${ }^{\mathrm{TM}}$ ) were obtained from the ATCC (Bethesda, MD, USA) and maintained in DMEM supplemented with $10 \%$ FBS, $2 \mathrm{mM}$ L-glutamine, $100 \mathrm{U} / \mathrm{mL}$ penicillin, and $100 \mu \mathrm{g} / \mathrm{mL}$ streptomycin at $37{ }^{\circ} \mathrm{C}$ in a $5 \% \mathrm{CO}_{2}$ incubator. After seeding of cells in 96 well culture plates, they were allowed to attach properly. Test compounds of different concentrations ranging from 1 to $50 \mu \mathrm{M}$ were added in triplicates and incubated for $24 \mathrm{~h}$. The cells were then incubated with MTT $(0.5 \mathrm{mg} / \mathrm{mL})$ for $3 \mathrm{~h}$ and, to dissolve the insoluble formazan crystals, $100 \mu \mathrm{L}$ DMSO was added to each well. Finally the absorbance of the plates was measured using a Synergy $\mathrm{H} 1$ multi-mode plate reader (USA). Doxorubicin was used as the positive control for comparison. 


\section{Supporting Information}

\section{Supporting Information File 1}

Copies of ${ }^{1} \mathrm{H}$ NMR, ${ }^{13} \mathrm{C}$ NMR, HRMS and DSC spectra.

[http://www.beilstein-journals.org/bjoc/content/

supplementary/1860-5397-13-4-S1.pdf]

\section{Acknowledgements}

Naganna Narra thanks the University Grants Commission (UGC), New Delhi, India, for financial support through a Senior Research Fellowship (UGC-SRF).

\section{References}

1. Figueroa-Espinoza, M.-C.; Villeneuve, P. J. Agric. Food Chem. 2005, 53, 2779. doi:10.1021/jf0484273

2. Shahidi, F.; Chandrasekara, A. Phytochem. Rev. 2010, 9, 147. doi:10.1007/s11101-009-9142-8

3. Garrido, J.; Gaspar, A.; Garrido, E. M.; Miri, R.; Tavakkoli, M.; Pourali, S.; Saso, L.; Borges, F.; Firuzi, O. Biochimie 2012, 94, 961. doi:10.1016/j.biochi.2011.12.015

4. Crauste, C.; Rosell, M.; Durand, T.; Vercauteren, J. Biochimie 2016, 120, 62. doi:10.1016/j.biochi.2015.07.018

5. Mbatia, B.; Kaki, S. S.; Mattiasson, B.; Mulaa, F.; Adlercreutz, P. J. Agric. Food Chem. 2011, 59, 7021. doi:10.1021/jf200867r

6. Sun, S.; Zhu, S.; Bi, Y. Food Chem. 2014, 158, 292. doi:10.1016/j.foodchem.2014.02.146

7. Yasa, S. R.; Kaki, S. S.; Bhaskara Rao, B.; Jain, N.; Penumarthy, V. Med. Chem. Res. 2016, 25, 1299. doi:10.1007/s00044-016-1564-4

8. Kaki, S. S.; Kunduru, K. R.; Kanjilal, S.; Prasad, R. B. N. J. Oleo Sci. 2015, 64, 845. doi:10.5650/jos.ess 15035

9. Hunneche, C. S.; Lund, M. N.; Skibsted, L. H.; Nielsen, J. J. Agric. Food Chem. 2008, 56, 9258. doi:10.1021/jf8024826

10. Van der Steen, M.; Stevens, C. V. ChemSusChem 2009, 2, 692. doi:10.1002/cssc.200900075

11. Sammaiah, A.; Kaki, S. S.; Sai Manoj, G. N. V. T.; Poornachandra, Y.; Kumar, C. G.; Prasad, R. B. N. Eur. J. Lipid Sci. Technol. 2015, 117, 692. doi:10.1002/ejlt.201400471

12. Doležalová, M.; Janiš, R.; Svobodová, H.; Kašpárková, V.; Humpolíček, P.; Krejčí, J. Eur. J. Lipid Sci. Technol. 2010, 112, 1106. doi:10.1002/ejlt.200900295

13. Tokiwa, Y.; Kitagawa, M.; Raku, T.; Yanagitani, S.; Yoshino, K. Bioorg. Med. Chem. Lett. 2007, 17, 3105. doi:10.1016/j.bmcl.2007.03.039

14. Jacobson, C. E.; Martinez-Muñoz, N.; Gorin, D. J. J. Org. Chem. 2015, 80, 7305. doi:10.1021/acs.joc.5b01077

15. Türünç, O.; Firdaus, M.; Klein, G.; Meier, M. A. R. Green Chem. 2012, 14, 2577. doi:10.1039/C2GC35982K

16. Chiu, M. H.; Prenner, E. J. J. Pharm. BioAllied Sci. 2011, 3, 39 doi:10.4103/0975-7406.76463

17. Silva, F. A. M.; Borges, F.; Guimarães, C.; Lima, J. L. F. C.; Matos, C.; Reis, S. J. Agric. Food Chem. 2000, 48, 2122. doi:10.1021/jf9913110

18. Stasiuk, M.; Kozubek, A. Cell. Mol. Life Sci. 2010, 67, 841. doi:10.1007/s00018-009-0193-1

19. Kaki, S. S.; Gopal, S. C.; Rao, B. V. S. K.; Poornachandra, Y.; Kumar, C. G.; Prasad, R. B. N. Eur. J. Lipid Sci. Technol. 2013, 115, 1123. doi:10.1002/ejlt.201300179
20. Sammaiah, A.; Padmaja, K. V.; Prasad, R. B. N.

Eur. J. Lipid Sci. Technol. 2016, 118, 495. doi:10.1002/ejlt.201500119

21. Kaki, S. S.; Arukali, S.; Padmaja, K. V.; Prasad, R. B. N.; Yedla, P.; Kumar, C. G. Bioorg. Med. Chem. Lett. 2016, 26, 209. doi:10.1016/j.bmcl.2015.10.086

22. Akowuah, G. A.; Zhari, I.; Norhayati, I.; Mariam, A. J. Food Compos. Anal. 2006, 19, 118. doi:10.1016/j.jfca.2005.04.007

23. Gaspar, A.; Martins, M.; Silva, P.; Garrido, E. M.; Garrido, J.; Firuzi, O.; Miri, R.; Saso, L.; Borges, F. J. Agric. Food Chem. 2010, 58, 11273. doi:10.1021/jf103075r

24. Reis, B.; Martins, M.; Barreto, B.; Milhazes, N.; Garrido, E. M.; Silva, P.; Garrido, J.; Borges, F. J. Agric. Food Chem. 2010, 58, 6986. doi:10.1021/jf100569j

25. Bollu, V. S.; Nethi, S. K.; Dasari, R. K.; Shiva Nageshwara Rao, S.; Misra, S.; Patra, C. R. Nanotoxicology 2015, 10, 413. doi:10.3109/17435390.2015.1073398

\section{License and Terms}

This is an Open Access article under the terms of the Creative Commons Attribution License (http://creativecommons.org/licenses/by/4.0), which permits unrestricted use, distribution, and reproduction in any medium, provided the original work is properly cited.

The license is subject to the Beilstein Journal of Organic Chemistry terms and conditions:

(http://www.beilstein-journals.org/bjoc)

The definitive version of this article is the electronic one which can be found at: doi:10.3762/bjoc. 13.4 